\title{
METODE ANALYTICAL HIERARCHY PROCESS: SISTEM REKOMENDER DATABASE SOFTWARE
}

\author{
Doni Purnama Alam Syah \\ Amik BSI Bandung \\ Jalan Sekolah Internasional No. 1-6 Antapani, Bandung 40282 \\ doni.dpa@bsi.ac.id
}

\begin{abstract}
Rekomender electoral system is a database software application that can be used to look for alternative software database selection strategy, the method of analytical hierarchy process (AHP). Rekomender systems needed by companies that have a large enough data processing such as the Bureau of Bina Sarana IT Information, expensive investments in the provision of Information Technology (IT) makes IT Bina Sarana Information Bureau to be more careful in determining the selection of database software. This study focuses on research of database software selection system with the method of analytical hierarchy process (AHP), a case study of IT Bureau Bina Sarana Infromatika with the observation unit administrator. The results of the study found that there are two (2) main criteria, namely the selection of technology and a user with an alternative strategy My SQL, Oracle and SQL Server. Having tested the system rekomender My SQL result that the top priority in the selection of database software with a $41 \%$ weighting, followed by SQL Server and Oracle 39\% 21\%. The end result of a system that has been created rekomender concluded that the Bureau of Bina Sarana Informatics IT can define strategy alternatives before determining database software to be used more effectively and efficiently.
\end{abstract}

\begin{abstract}
Abstrak - Sistem rekomender pemilihan database software merupakan aplikasi yang dapat digunakan untuk mencari alternatif strategi pemilihan database software, dengan metode analytical hierarchy process (AHP). Sistem rekomender dibutuhkan oleh perusahaan yang memiliki pengolahan data yang cukup besar seperti Biro TI Bina Sarana Informatika, mahalnya investasi pada penyediaan Teknologi Informasi (TI) membuat Biro TI Bina Sarana Informatika lebih berhati-hati dalam menentukan pemilihan database software. Penelitian ini berfokus kepada penetilian tentang sistem pemilihan database sofware dengan metode analytical hierarchy process (AHP), studi kasus Biro TI Bina Sarana Infromatika dengan unit observasi bagian Administrator. Hasil dari penelitian ditemukan bahwa terdapat 2 (dua) kriteria utama pemilihan yaitu technology dan user dengan alternatif strategi My SQL, Oracle dan SQL Server. Setelah diuji coba sistem rekomender didapat hasil bahwa My SQL menjadi prioritas utama dalam pemilihan database software dengan bobot nilai $41 \%$ yang diikuti oleh SQL Server 39\% dan Oracle $21 \%$. Hasil akhir dari sistem rekomender yang telah diciptakan disimpulkan bahwa Biro TI Bina Sarana Informatika dapat menentukan alternatif strategi sebelum menentukan database software yang akan digunakan lebih efektif dan efisien.
\end{abstract}

Kata Kunci: Sistem Rekomender, Database Software, Analytical Hierarchy Process

\section{PENDAHULUAN}

Tahun 2010 peran dari Teknologi Informasi atau Sistem Informasi saat ini mengalami pergeseran dari hanya sebagai pendukung saja menjadi alat untuk melakukan proses operasional dan mendukung pengambilan keputusan yang strategis. Teknologi Informasi (TI) merupakan salah satu faktor yang sangat berperan dalam kesuksesan dan kelangsungan suatu perusahaan dalam menjalankan proses bisnisnya karena selaindapat memberikan keuntungan dalam bersaing, optimalisasi perusahaan juga dapat terwujud. Investasi TI yang begitu mahal akan dapat memberikan kontribusi yang positif terhadap suatu perusahaan, dan diharapkan keputusan untuk investasi TI tidak semata-mata hanya untuk mengikuti tren teknologi yang ada tanpa dapat memberikan manfaat yang besar terhadap perusahaan. Selain itu TI seharusnya dapat dijadikan sebagai alat untuk bersaing jika sistem TI yang ada memang masih layak dan mampu mendukung kegiatan operasional organisasi. Dalam memanfaatkan kapasitas sistem TI yang ada perusahaan harus lebih 
kreatif dalam mengeksplorasi fungsi TI demi peningkatan kinerja perusahaan. Penerapan TI yang handal harus dapat memperkirakan potensi resiko yang akan terjadi bagi suatu organisasi apabila terjadi kegagalan sistem akibat bencana atau keadaan darurat sehingga sistem yang merupakan penunjang utama proses bisnis akan tetap berfungsi dengan baik. Database merupakan bagian penting dalam perusahaan dimana semua data perusahaan berpusat dalam satu tempat untuk diolah dan didistribusikan. Pemilihan Database Software yang tepat untuk pengolahan Database merupakan tolak awal keamanan data perusahaan, karena banyak rahasia perusahaan yang terdapat dalam database seperti data mahasiswa, keuangan dll.

Bina Sarana Informatika (BSI) merupakan institusi pendidikan yang mengutamakan IT, banyak data yang diolah oleh BSI dalam kegiatan bisnisnya. Saat ini BSI menggunakan software pengolahan database karena kebutuhannya untuk pengolahan data yang dibutuhkan oleh bagian dalam intitusi yaitu BIP, BAAK, BAU dan BTI untuk dikelola agar proses bisnis dari Akademik BSI berjalan lancar.

Banyaknya pilihan pendukung sistem basis data atau software pengolah database yang mengakibatkan munculnya ide pengambilan keputusan mana software sistem basis data yang sesuai dengan kebutuhan institusi yang disesuaikan dengan Visi dan Misi Institusi. Pada departemen pemasaran Davies (2001) mengemukakan pentingnya penggunaan metode AHP untuk pendukung keputusan, hal lain juga disampaikan Danner et al (2011) dalam bidang kesehatan digunakan metode AHP untuk preferensi pasien. Pentingnya metode AHP sehingga sering digunakan diberbagai bidang di perusahaan untuk pendukung keputusan terutama untuk mengevaluasi bidang Teknologi Informasi (TI) (Kord \& Eslamkhah, 2011). Parthasarathy \& Anbazhagan (2007) menggunakan metode AHP untuk mengevaluasi software, dimana memiliki manfaat yang besar untuk perusahaan, mengingat inventasi bidang Teknologi Informasi cukup besar. Sehingga perlu dikaji sistem pendukung keputusan dalam pemilihan database menggunakan metode AHP, terutama pada Biro TI Bina Sarana Informatika yang menggunakan pengolahan database yang cukup besar dibidang pendidikan.

Penelitian ini akan melakukan kajian tentang faktor-faktor penunjang keputusan pemilihan software sistem basis data (Database). Sejumlah kriteria dan sub-kriteria yang dibentuk akan menggunakan pendekatan terhadap segi technology dan user. Analisa teknis akan menggunakan metode proses analisa hirarki atau yang dikenal dengan Analytical hierarchy process (AHP). Analisa ini diharapkan mampu memberikan pilihan dalam proses pengambilan keputusan dalam strategi implementasi Database Software.

\section{KAJIAN LITERATUR}

\section{Strategi Teknologi Informasi}

Kata strategi berasal dari bahasa Yunani yaitu "strategos" yang berarti komandan militer pada zaman demokrasi Athena. Secara formal strategi dapat didefinisikan sebagai rencana jangka panjang dengan diikuti tindakantindakan yang ditujukan untuk mencapai tujuan tertentu yang umumnya adalah suatu kemenangan (Carpenter, 2005). Sebagai contoh strategi bisnis yang paling terkenal yaitu "Competitive Strategy" yang dikembangkan oleh Porter dan "Strategy Concept I: Five Ps for Strategy" \& "Strategy Concept II: Another Look at Why Organizations Need Strategies" yang dikembangkan oleh Richard (2009)

Menurut Gerry Johnson dan Kevan Scholes (dalam bukunya "Exploring Corporate Strategy") strategi juga didefinisikan sebagai arah dan cakupan jangka panjang organisasi untuk mendapatkan keunggulan melalui konfigurasi sumber daya alam dan lingkungan yang berubah untuk mencapai kebutuhan pasar dan memenuhi harapan pihak yang berkepentingan (stakeholder) (Carpenter, 2005).

Supratikto (2009) mengatakan bahwa dalam suatu organisasi, strategi dapat dikembangkan melalui lima tahapan. Arsitektur organisasi berkaitan dengan jawaban terhadap tiga hal mendasar, yaitu siapa saja yang memiliki kewenangan untuk memutuskan tentang sesuatu hal (distribution of authority), siapa saja yang memberi kontribusi apa dan bagaimana mengukurnya (performance appraisal), dan siapa saja yang memperoleh apa dan berapa banyak (reward system).

Bagi suatu organisasi, memiliki strategi bisnis saja tidaklah cukup untuk menghadapi persaingan dewasa ini, namun harus pula dilengkapi dengan Strategi Teknologi Informasi atau IT Strategy sehingga penggunaan Teknologi Informasi sebagai komponen utama Sistem Informasi organisasi dapat dimanfaatkan secara optimum.

Menurut Sinaga (2008) dalam penelitiannya yang berjudul "Strategi Proses Migrasi Proprietary Software ke Open Source Software 
di Perusahaan dengan Pendekatan Analytical Hierarchy Process (AHP). Studi Kasus : SGU, Tangerang", untuk menghasilkan strategi teknologi yang baik maka diperlukan tiga komponen utama, antara lain Sistem Informasi, Teknologi Informasi dan Manajemen Informasi. Menyangkut perangkat manusia (brainware) yang akan mengimplementasikan Sistem Informasi yang dibangun dan mengembangkan Teknologi Informasi sejalan dengan perkembangan organisasi di masa mendatang. Menurut Earl (2000), suatu organisasi dapat melakukan identifikasi metode pengembangan TI berdasarkan pada lima tipe pendekatan yaitu Business led, Method driven, Technological, Administrative, dan Organizational. Investasi SI/TI didasarkan pada konsensus bisnis tentang bagaimana SI/TI dapat membantu pencapaian sasaran bisnis.

Mengambil keputusan adalah suatu proses yang dilaksanakan orang berdasarkan pengetahuan dan informasi yang ada dengan harapan bahwa akan terjadi. Keputusan dapat diambil dari alternatif-alternatif keputusan yang ada. Alternatif keputusan itu dapat dilakukan dengan adanya informasi yang diolah dan disajikan dengan dukungan sistem penunjang keputusan. Adapun informasi terbentuk dari adanya data yang terdiri dari bilangan dan terms yang disusun, diolah, dan disajikan dengan dukungan sistem informasi manajemen.

\section{Sistem Rekomender}

Sistem Rekomendasi (SR) merupakan model aplikasi dari hasil observasi terhadap keadaan dan keinginan pelanggan. Sistem Rekomendasi memanfaatkan opini seseorang terhadap suatu barang dalam domain atau kategori tertentu, untuk membantu seseorang dalam memilih produk. Karena itu SR memerlukan model rekomendasi yang tepat agar apa yang direkomendasikan sesuai dengan keinginan pelanggan, serta mempermudah pelanggan mengambil keputusan yang tepat dalam menentukan produk yang akan dibelinya (Purwanto, 2009).

Knowledge-based recommendation merupakan metode yang memanfaatkan perzonalization rule pada knowledge-based (basis pengetahuan) . Perzonalization rule merupakan aturan-aturan yang dirancang pada basis pengetahuan dengan skala prioritas tertentu. Skala prioritas diatur tingkatannya berdasarkan prediksi prioritas kebutuhan pelanggan terhadap suatu produk (item). Produk yang memenuhi prioritas terbanyak akan dijadikan rekomendasi bagi pelanggan.

Utility-based recommendation merupakan metode yang memanfaatkan score (nilai kegunaan ) suatu produk sebagai acuannya. Suatu produk dinilai pada tiap domain penilaian, setelah itu score produk pada tiap domain dihitung secara total. Produk yang memiliki total score terbesarlah yang akan dijadikan rekomendasi bagi pelanggan. Prioritas domain penilaian diatur oleh pelanggan, dengan kata lain domain penilaian dengan tingkat prioritas lebih tinggi akan memiliki score lebih tinggi pula. Metode ini hampir sama dengan Metode Bayasian Network. Sistem rekomender dapat digunakan untuk pendukung keputusan bidang Teknologi Informasi menggunakan metode AHP (Cheng \& Li, 2001).

\section{Basis Data (Database)}

Edgar F. Codd memperkenalkan istilah ini pada makalah seminarnya yang berjudul "A Relational Model of Data for Large Shared Data Banks". Salah satu definisi yang cukup dikenal secara luas atas sebuah sistem basisdata relasional adalah 12 hukum Codd. Namun demikian, pada awal-awal implementasinya banyak model relasional yang tidak mengikuti seluruh elemen-elemen yang terdapat dalam hukum-hukum Codd tersebut yang menjadikan terminologinya berkembang untuk mendeskripsikan sebuah tipikal sistem basisdata yang lebih luas.

Data merupakan fakta mengenai suatu objek seperti manusia, benda, peristiwa, konsep, keadaan dan sebagainya yang dapat dicatat dan mempunyai arti secara implisit. Data dapat dinyatakan dalam bentuk angka, karakter atau simbol, sehingga bila data dikumpulkan dan saling berhubungan maka dikenal dengan istilah basis data (Dzacko, 2007). Sedangkan menurut George Tsu-der Chou basis data merupakan kumpulan informasi bermanfaat yang diorganisasikan ke dalam aturan yang khusus. Informasi ini adalah data yang telah diorganisasikan ke dalam bentuk yang sesuai dengan kebutuhan seseorang (Kadir, 2005). Menurut Encyclopedia of Computer Science and Engineer, para ilmuwan di bidang informasi menerima definisi standar informasi yaitu data yang digunakan dalam pengambilan keputusan. Definisi lain dari basis data menurut Dzacko (2007) adalah sistem berkas terpadu yang dirancang terutama untuk meminimalkan duplikasi data. Menurut Dzacko (2007) mendefinisikan basis data lebih dibatasi pada arti implisit yang khusus, yaitu:

1. Basis data merupakan penyajian suatu aspek dari dunia nyata (real world).

2. Basis data merupakan kumpulan data dari berbagai sumber yang secara logika 
mempunyai arti implisit. Sehingga data yang terkumpul secara acak dan tanpa mempunyai arti, tidak dapat disebut basis data.

3. Basis data perlu dirancang, dibangun dan data dikumpulkan untuk suatu tujuan. Basis data dapat digunakan oleh beberapa user dan beberapa aplikasi yang sesuai dengan kepentingan user.

Dari beberapa definisi-definisi tersebut, dapat dikatakan bahwa basis data mempunyai berbagai sumber data dalam pengumpulan data, bervariasi derajat interaksi kejadian dari dunia nyata, dirancang dan dibangun agar dapat digunakan oleh beberapa user untuk berbagai kepentingan (Waliyanto, 2000).

Gabungan antara basis data dan perangkat lunak SMBD (Sistem Manajemen Basis Data) termasuk di dalamnya program aplikasi yang dibuat dan bekerja dalam satu sistem disebut dengan Sistem Basis Data (Waliyanto, 2000).

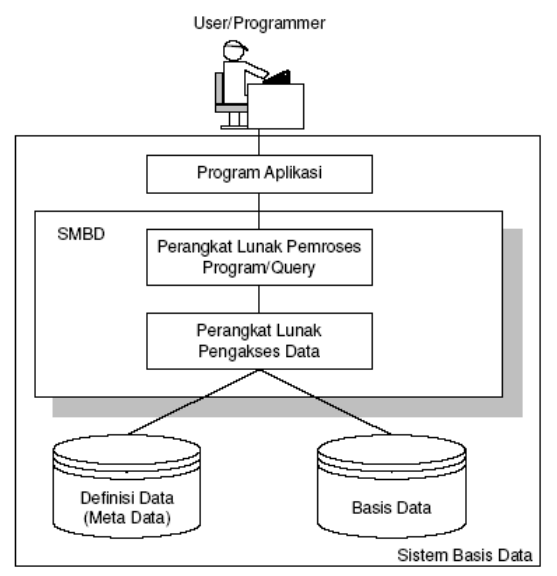

Gambar 1

Konsep sistem basis data

Sistem basis data dapat dianggap sebagai tempat untuk sekumpulan berkas data yang terkomputerisasi dengan tujuan untuk memelihara informasi dan membuat informasi tersebut tersedia saat dibutuhkan.

Metode Analytical Hierarchy Process (AHP) Metode AHP dikembangkan oleh Thomas L. Saaty, seorang ahli matematika. Metode ini adalah sebuah kerangka untuk mengambil keputusan dengan efektif atas persoalan yang kompleks dengan menyederhanakan dan mempercepat proses pengambilan keputusan dengan memecahkan persoalan tersebut kedalam bagian-bagiannya, menata bagian atau variabel ini dalam suatu susunan hirarki, member nilai numerik pada pertimbangan subjektif tentang pentingnya tiap variabel dan mensintesis berbagai pertimbangan ini untuk menetapkan variabel yang mana yang memiliki prioritas paling tinggi dan bertindak untuk mempengaruhi hasil pada situasi tersebut. Metode AHP ini membantu memecahkan persoalan yang kompleks dengan menstruktur suatu hirarki kriteria, pihak yang berkepentingan, hasil dan dengan menarik berbagai pertimbangan guna mengembangkan bobot atau prioritas. Metode ini juga menggabungkan kekuatan dari perasaan dan logika yang bersangkutan pada berbagai persoalan, lalu mensintesis berbagai pertimbangan yang beragam menjadi hasil yang cocok dengan perkiraan kita secara intuitif sebagaimana yang dipresentasikan pada pertimbangan yang telah dibuat. (Saaty, 2008).

Menurut Saaty (2008), ada tiga prinsip dalam memecahkan persoalan dengan AHP, yaitu prinsip menyusun hirarki (Decomposition), prinsip menentukan prioritas (Comparative Judgement), dan prinsip konsistensi logis (Logical Consistency). Hirarki yang dimaksud adalah hirarki dari permasalahan yang akan dipecahkan untuk mempertimbangkan kriteriakriteria atau komponenkomponen yang mendukung pencapaian tujuan. Dalam proses menentukan tujuan dan hirarki tujuan, perlu diperhatikan apakah kumpulan tujuan beserta kriteria-kriteria yang bersangkutan tepat untuk persoalan yang dihadapi.

Dalam memilih kriteria-kriteria pada setiap masalah pengambilan keputusan perlu memperhatikan kriteria-kriteria sebagai berikut:

1. Lengkap

Kriteria harus lengkap sehingga mencakup semua aspek yang penting, yang digunakan dalam mengambil keputusan untuk pencapaian tujuan.

2. Operasional

Operasional dalam artian bahwa setiap kriteria ini harus mempunyai arti bagi pengambil keputusan, sehingga benarbenar dapat menghayati terhadap alternatif yang ada, disamping terhadap sarana untuk membantu penjelasan alat untuk berkomunikasi.

3. Tidak berlebihan

Menghindari adanya kriteria yang pada dasarnya mengandung pengertian yang sama.

4. Minimum

Diusahakan agar jumlah kriteria seminimal mungkin untuk mempermudah pemahaman terhadap persoalan, serta menyederhanakan persoalan dalam analisis. 
Saaty (2008) mengatakan bahwa AHP dapat digunakan dalam memecahkan berbagai masalah diantaranya untuk mengalokasikan sumber daya, analisis keputusan manfaat atau biaya, menentukan peringkat beberapa alternatif, melaksanakan perencanaan ke masa depan yang diproyeksikan dan menetapkan prioritas pengembangan suatu unit usaha dan permasalahan kompleks lainnya. Secara umum, langkah-langkah dasar dari AHP dapat diringkas dalam penjelasan berikut ini:

1. Mendefinisikan masalah dan menetapkan tujuan. Bila AHP digunakan untuk memilih alternatif atau penyusunan prioritas alternatif, maka pada tahap ini dilakukan pengembangan alternatif.

2. Menyusun masalah dalam struktur hirarki. Setiap permasalahan yang kompleks dapat ditinjau dari sisi yang detail dan terstruktur.

3. Menyusun prioritas untuk tiap elemen masalah pada tingkat hirarki. Proses ini menghasilkan bobot elemen terhadap pencapaian tujuan, sehingga elemen dengan bobot tertinggi memiliki prioritas penanganan. Langkah pertama pada tahap ini adalah menyusun perbandingan berpasangan yang ditransformasikan dalam bentuk matriks, sehingga matriks ini disebut matriks perbandingan berpasangan.

Pengambilan Keputusan Dengan Analytical Hierarchy Process (AHP)

Pengambilan keputusan dapat dilakukan dengan dua kerangka kerja, meliputi:

1. Pengambilan keputusan tanpa percobaan

2. Pengambilan keputusan yang berdasarkan suatu percobaan.

Amborowati (2007) mengatakan pengambilan keputusan tanpa berdasarkan eksperimen, dilakukan dengan cara menyusun secara sistematis cara kerja umum sebelum mencari solusi bagi masalah yang diharapkan. Teori ini dikembangkan sejalan dengan pendekatan statistik di mana secara sederhana, keputusan yang dihasilkan diupayakan mempunyai pengaruh kesalahan seminimum mungkin.

Dalam kehidupan sehari-hari pengambilan keputusan sering menggunakan intuisi, walaupun metode ini banyak sekali kekurangan sehingga dikembangkan sistematika baru yang disebut dengan analisis keputusan, yaitu kecerdasan, persepsi, dan falsafah. Setelah menggunakan kecerdasan, persepsi, dan falsafah untuk membuat model, menentukan nilai kemungkinan, menetapkan nilai pada hasil yang diharapkan dan menjajaki preferensi terhadap waktu dan preferensi terhadap resiko, maka untuk sampai pada suatu keputusan diperlukan logika.

Dari informasi awal yang dikumpulkan, dilakukan pendefinisian dan penghubungan variabel-variabel yang mempengaruhi keputusan pada tahap deterministik. Setelah itu dilakukan penetapan nilai untuk mengukur tingkat kepentingan variabel-variabel tersebut tanpa memperhatikan unsur-unsur ketidakpastian.

Salah satu model yang dapat digunakan sebagai proses pengambilan keputusan adalah dengan menggunakan Proses Hierarki Analitik atau yang dikenal dengan istilah Analytical Hierarchy Process (AHP).

Proses Hierarki Analitik (AHP) dikembangkan oleh Dr. Thomas L. Saaty dari Wharton School of Business pada tahun 1970-an untuk mengorganisasikan informasi dan judgement dalam memilih alternatif yang paling disukai (Saaty, 2008). Dengan menggunakan AHP, suatu persoalan yang akan dipecahkan dalam suatu kerangka berpikir yang terorganisir, sehingga memungkinkan dapat diekspresikan untuk mengambil keputusan yang efektif atas persoalan tersebut. Persoalan yang kompleks dapat disederhanakan dan dipercepat proses pengambilan keputusannya.

Prinsip kerja AHP adalah menyederhanakan suatu persoalan kompleks yang tidak terstruktur, stratejik, dan dinamik menjadi bagian-bagiannya, serta menata dalam suatu hierarki. Kemudian tingkat kepentingan setiap variabel diberi nilai numerik secara subjektif tentang arti penting variabel tersebut secara relatif dibandingkan dengan variabel lain. Dari berbagai pertimbangan tersebut kemudian dilakukan sintesa untuk menetapkan variabel yang memiliki prioritas tertinggi dan peranan untuk mempengaruhi hasil pada sistem tersebut.

Secara grafis, persoalan keputusan AHP dapat dikonstruksikan sebagai diagram bertingkat, yang dimulai dengan goal/sasaran, lalu kriteria level pertama, sub kriteria, dan akhirnya alternatif. AHP memungkinkan pengguna untuk memberikan nilai bobot relatif dari suatu kriteria majemuk (atau alternatif majemuk terhadap suatu kriteria) secara intuitif, yaitu dengan melakukan perbandingan berpasangan (pairwise comparisons). Dr. Thomas L. Saaty, pembuat AHP, kemudian menentukan cara yang konsisten untuk mengubah perbandingan berpasangan/pairwise, menjadi suatu himpunan bilangan yang merepresentasikan prioritas relatif dari setiap kriteria dan alternatif.

AHP memilki banyak keunggulan dalam menjelaskan proses pengambilan keputusan, karena dapat digambarkan secara grafis, 
sehingga dapat dipahami oleh semua pihak yang terlibat dalam pengambilan keputusan. Dengan AHP, proses keputusan kompleks dapat diuraikan menjadi keputusan-keputusan lebih kecil yang dapat ditangani lebih mudah.

Selain itu, AHP juga menguji konsistensi penilaian, bila terjadi penyimpangan yang terlalu jauh dari nilai konsistensi sempurna maka hal ini menunjukkan bahwa penilaian perlu diperbaiki, atau hierarki harus distruktur ulang.

Beberapa keuntungan yang diperoleh bila memecahkan persoalan pengambilan keputusan dengan menggunakan AHP adalah sebagai berikut.

Tabel 1

Keuntungan AHP

\begin{tabular}{|c|c|}
\hline Keuntungan & Keterangan \\
\hline Kesatuan & $\begin{array}{l}\text { AHP memberikan satu model } \\
\text { tunggal yang mudah } \\
\text { dimengerti, luwes untuk } \\
\text { aneka ragam persoalan tidak } \\
\text { terstruktur }\end{array}$ \\
\hline Kompleksitas & $\begin{array}{lc}\text { AHP memadukan } & \text { ancangan } \\
\text { deduktif dan } & \text { ancangan } \\
\text { berdasarkan sistem dalam } \\
\text { memecahkan } \\
\text { kompleks }\end{array}$ \\
\hline $\begin{array}{l}\text { Saling } \\
\text { Ketergantung } \\
\text { an }\end{array}$ & $\begin{array}{l}\text { AHP dapat menangani saling } \\
\text { ketergantungan } \\
\text { elemen dalam suatu sistem } \\
\text { dan tidak memaksakan } \\
\text { pemikiran linear }\end{array}$ \\
\hline $\begin{array}{l}\text { Penyusunan } \\
\text { Hierarki }\end{array}$ & $\begin{array}{l}\text { AHP mencerminkan } \\
\text { kecendrungan alami pikiran } \\
\text { untuk memilah-milah elemen- } \\
\text { elemen suatu sistem dalam } \\
\text { berbagai tingkat berlainan dan } \\
\text { mengelompokkan unsur yang } \\
\text { serupa dalam setiap tingkat }\end{array}$ \\
\hline Pengukuran & $\begin{array}{l}\text { AHP memberi suatu skala } \\
\text { untuk mengukur hal-hal dan } \\
\text { terwujud suatu metode untuk } \\
\text { menetapkan prioritas }\end{array}$ \\
\hline Konsistensi & $\begin{array}{l}\text { AHP melacak konsistensi } \\
\text { logis dari pertimbangan- } \\
\text { pertimbangan yang digunakan } \\
\text { untuk menetapkan berbagai } \\
\text { prioritas }\end{array}$ \\
\hline Sintesis & $\begin{array}{l}\text { AHP menuntun ke suatu } \\
\text { taksiran menyeluruh tentang } \\
\text { kebaikan setiap altrnatif }\end{array}$ \\
\hline $\begin{array}{l}\text { Tawar } \\
\text { Menawar }\end{array}$ & $\begin{array}{l}\text { AHP mempertimbangkan } \\
\text { prioritas-prioritas relatif dari } \\
\text { berbagai faktor sistem dan } \\
\text { memungkinkan organisasi } \\
\text { memilih alternatif terbaik }\end{array}$ \\
\hline
\end{tabular}

\begin{tabular}{|c|c|}
\hline & $\begin{array}{l}\text { berdasarkan } \\
\text { mereka }\end{array}$ \\
\hline $\begin{array}{l}\text { Penilaian dan } \\
\text { Konsesus }\end{array}$ & $\begin{array}{lrr}\text { AHP tidak memaksakan } \\
\text { konsensus } & \text { tetapi } \\
\text { mensintesiskan suatu } & \text { hasil } \\
\text { yang representatif } & \text { dari } \\
\text { berbagai penilaian } & \text { yang } \\
\text { berbeda } & & \\
\end{array}$ \\
\hline $\begin{array}{l}\text { Pengulangan } \\
\text { Proses }\end{array}$ & $\begin{array}{l}\text { AHP memungkinkan } \\
\text { organisasi memperhalus } \\
\text { defenisi mereka pada suatu } \\
\text { persoalan dan memperbaiki } \\
\text { pertimbangan dan pengertian } \\
\text { mereka melalui pengulangan }\end{array}$ \\
\hline
\end{tabular}

Selanjutnya prinsip kerja AHP adalah sebagai berikut :

1. Penyusunan Hierarki

Persoalan yang akan diselesaikan diuraikan menjadi unsur-unsurnya, yaitu kriteria dan alternatif, kemudian disusun menjadi struktur hirarki.

2. Penilaian Kriteria dan Alternatif

Kriteria dan alternatif dinilai melalui perbandingan berpasangan. Menurut Saaty (2008), untuk berbagai persoalan, skala 1 sampai 9 adalah skala terbaik dalam mengekspresikan pendapat.

3. Penentuan Prioritas

Untuk setiap kriteria dan alternatif, perlu dilakukan perbandingan berpasangan (pairwise comparisons). Nilai-nilai perbandingan relatif kemudian diolah untuk menentukan peringkat relatif dari seluruh alternatif.

Baik kriteria kualitatif maupun kriteria kuantitatif dapat dibandingkan sesuai dengan judgement yang telah ditentukan untuk menghasilkan bobot dan prioritas. Bobot atau prioritas dihitung dengan manipulasi matrik atau melalui penyelesaian persamaan matematik.

4. Konsistensi Logis

Semua elemen dikelompokkan secara logis dan diperingkatkan secara konsisten sesuai dengan suatu kriteria yang logis.

\section{Telaahan Penelitian Terdahulu}

Fard et al (2011) mengemukakan bahwa AHP dapat digunakan dalam sistem pendukung keputusan pada bidang Teknologi Informasi, Wan et al (2011) juga menggunakan metode AHP untuk mengevaluasi Sistem Informasi pada perusahaan. Menginduk dari Alanbay (2005) yang melakukan penelitian terhadap proses seleksi aplikasi perangkat lunak ERP menggunakan metode AHP. Terdapat tiga kriteria utama yang terkait satu dengan lainnya yaitu: 
1. Kriteria Technology Related

2. Kriteria User related

3. Kriteria Vendor Related

Alanbay (2005) berpendapat bahwa kriteria User Related dapat digabung dengan kriteria dari Technology Related.

Kriteria Technology Related memberikan efek terhadap kemudahan pemakaian aplikasi untuk para pemakai, akan tetapi dalam beberapa subkriteria ada hal yang memang tidak terkait dengan pemakai. Untuk lebih membedakan hal-hal khusus, maka dilakukan pembedaaan terhadap kedua hal tersebut.

Tabel 2

Sub Kriteria dari Penelitian

\begin{tabular}{cl}
\hline No & \multicolumn{1}{c}{ Sub Kriteria } \\
\hline 1 & Customization \\
\hline 2 & Implementability \\
\hline 3 & Maintenance \\
\hline 4 & Real Time Changes \\
\hline 5 & Flexibility \\
\hline 6 & User Friendliness \\
\hline 7 & Cost \\
\hline 8 & System Requirements \\
\hline 9 & After Sales Support and Trainin \\
\hline 10 & Back-Up System \\
\hline 11 & Reporting \& Analysis Features \\
\hline 12 & Vendor Credentials \\
\hline 13 & Integration with Other software \\
\hline 14 & Internet Integration \\
\hline 15 & Financing Options \\
\hline
\end{tabular}

Sumber: Alanbay (2005)

Beberapa sub-kriteria yang disusun yaitu sebagai berikut:

1. Customization, adaptasi sistem terhadap beberapa organisasi yang berbeda.

2. Implementability, setiap aplikasi ERP mempunyai kebutuhan yang berbeda, sehingga penting untuk memilih aplikasi yang dapat diimplementasikan.

3. Maintenance, aplikasi mampu mendukung banyak perusahaan, banyak divisi dan mata uang yang bermacam-macam. Tidak boleh ada restriksi terhadap hal ini.

4. Real Time Changes, modul dari aplikasi ERP mampu untuk melakukan proses secara langsung dan waktu yang cepat.

5. Flexibility, mampu untuk dikembangkan bila ada kebutuhan bisnis yang berubah saat telah diimplementasikan sesuai dengan strategi bisnisnya.

6. User Friendliness, pemakai akhir bukanlah seorang ahli dalam bidang komputer, sehingga aplikasi dapat dijalankan dengan mudah dan efisien.
7. Cost, biaya merupakan isu yang sangat dominan dan aplikasi ERP pada dasarnya merupakan sistem yang kompleks dengan biaya implementasi yang tinggi dan tetap bisa masuk dalam anggaran yang tersedia.

8. System Requirements, sangat penting untuk memilih ERP yang tidak tergantung terhadap perangkat keras, perangkat lunak, sistem operasi maupun basis data. Desain dari aplikasi ERP tidak konflik dengan strategi bisnis dari organisasi

9. After Sales Support and Training, vendor mampu memberikan pelatihan dan dukungan terbaiknya dan pelatihan diberikan kepada seluruh pemakai sistem

10. Back-Up System, ERP sistem merupakan aplikasi yang besar dan kompleks, oleh karena itu pemakai dapat dengan mudah melakukan jadwal rutin untuk menyimpan data dalam tempat cadangan lainnya.

11. Reporting \& Analysis Features, selain laporan baku yang dihasilkan, pihak manajemen dapat juga untuk membuat pelaporan yang diinginkannya.

12. Vendor Credentials, reputasi dari vendor, konsultan yang berpengalaman, jumlah instalasi yang telah dilakukan serta komitmen dalam melakukan implementasi pada kliennya.

13. Integration with Other software, modulmodul dari aplikasi ERP mampu untuk berintegrasi degan modul lainnya atau mempunyai kemampuan untuk melakukan pertukaran data.

14. Internet Integration, aplikasi ERP mampu mendukung elektronik bisnis, ataupun transaksi pertukaran dengan sistem lainnya, serta tambahan fitur untuk adaptasi dengan internet transaksi.

15. Financing Options, bukanlah merupakan kriteria teknis, tapi cukup penting buat organisasi dalam melakukan pembayaran investasi aplikasi ERP.

Model AHP ini, memberikan dua alternatif pilihan aplikasi ERP yaitu SAP dan AXAPTA,:

Pada penelitian sistem rekomender pemilihan database software menggunakan metode AHP yang dikaji diambil dari 2 kriteria penting yaitu Technologi Related dan User Related. Alternatif pilihan yang akan dikaji terdapat 3 (tiga) produk dari vendor yang berbeda yaitu My SQL, Oracle dan SQL Server.

model AHP selengkapnya dapat dilihat sebagai berikut 


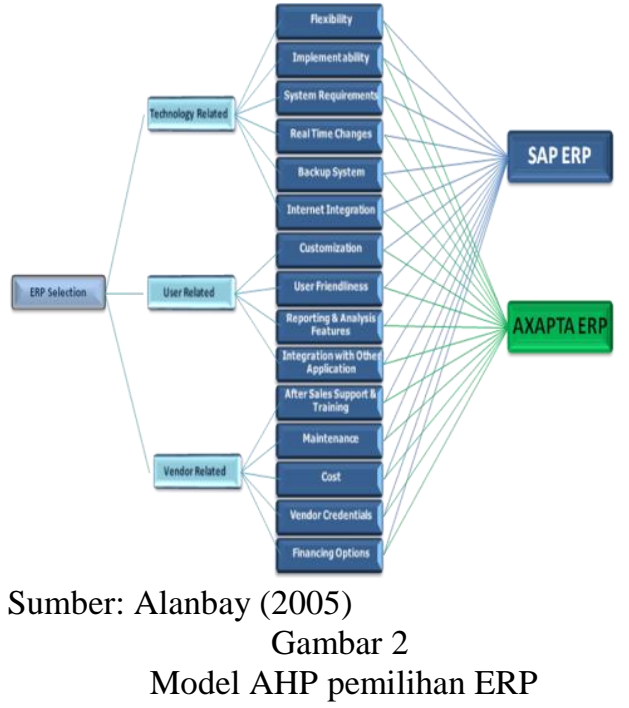

\section{METODE PENELITIAN}

Penelitian terapan (applied research) dilakukan dengan terlebih dahulu mempelajari teori-teori dan penelitian terdahulu (library research), dilanjutkan dengan pembuatan system pendukung keputusan dan survei (survey research) yaitu pengisian kuesioner untuk mengumpulkan data sampel pada suatu waktu tertentu (cross-sectional survey) dari pengguna software database. Jenis penelitian adalah eksploratif yaitu penggalian fakta terhadap proses alternatif pilihan dalam strategi pemilihan database software, studi kasus pada Bina Sarana Informatika.

Metode yang digunakan adalah Purposive Sampling, yaitu dilakukan pengambilan sampel atas dasar pertimbangan tertentu (Jogiyanto, 2008). Terdapat dua jenis pengisian kuesioner yang akan digunakan pada dua hipotesa sesuai dengan penjelasan mengenai kerangka konsep.

Kuesioner digunakan untuk memilih database software yang akan digunakan sebagai sentralisasi data. Responden dipilih dari bagian Data Administrator di Biro Teknologi Informasi (BTI) Bina Sarana Informatika dengan jumlah responden yang akan dipilih adalah semua karyawan bagian Data Administrator yaitu 6 orang.

Strategi pengumpulan data didasari opini dari individu atau responden dan dilakukan dengan teknik survei yang diperoleh dari kuesioner

\section{Instrument Penelitian}

Instrument Penelitian utama yang digunakan dalam penelitian ini adalah kuesioner.

Berikutnya kriteria dan sub kriteria yang digunakan dalam penelitian ini dapat dijelaskan pada table berikut ini :
Tabel 3

Kriteria dan Sub Kriteria instrument Penelitian

\begin{tabular}{|c|c|c|}
\hline Kriteria & Sub Kriteria & Pilihan \\
\hline \multirow{7}{*}{$\begin{array}{c}\text { Technology } \\
\text { Related }\end{array}$} & Flexibility & \multirow{7}{*}{$\begin{array}{c}M y \\
S Q L \\
\text { Oracle }\end{array}$} \\
\hline & Implement ability & \\
\hline & System & \\
\hline & Requirements & \\
\hline & Real Time Changes & \\
\hline & Backup System & \\
\hline & Internet Integration & \\
\hline \multirow{6}{*}{$\begin{array}{c}\text { User } \\
\text { Related }\end{array}$} & Customization & \multirow{6}{*}{$\begin{array}{c}S Q L \\
\text { Server }\end{array}$} \\
\hline & User Friendliness & \\
\hline & Reporting \& & \\
\hline & Analysis Features & \\
\hline & Integration with & \\
\hline & Other Application & \\
\hline
\end{tabular}

Dalam bentuk grafik untuk instrument penelitian dapat dilihat pada gambar dibawah ini :

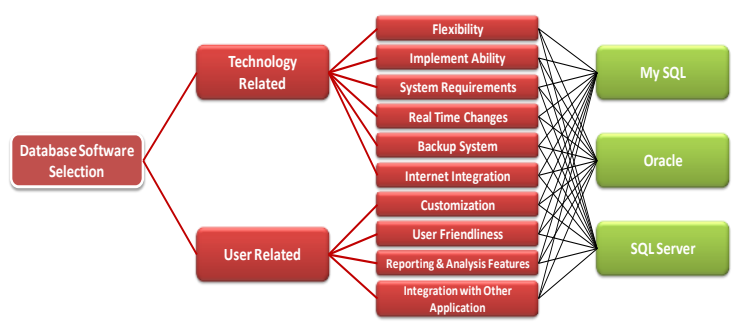

Gambar 3

Diagram hirarki dan keputusan

\section{Teknis Analisis Data}

Pada penelitian ini teknis analisis data melaui 2 (dua) tahap yaitu pertama pembuatan aplikasi system rekomender dengan metode Analytical Hierarchy Process (AHP), kedua kuesioner pemilihan database software menggunakan aplikasi system rekomender.

Pada tahap petama yaitu pembuatan aplikasi system rekomender menggunakan pendekatan AHP dengan bahasa pemrograman Microsoft Visual Basic 6.0 dan yang memiliki 4 (empat) langkah sebagai berikut :

1. Langkah 1, menyusun Diagram Kirarki AHP

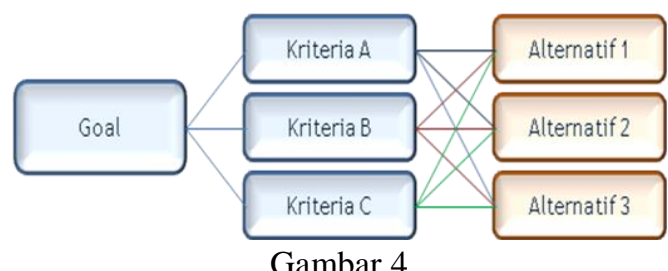

Contoh Bentuk Hirarki

Gambar di atas hanya merupakan contoh semata, kenyataannya bentuk hirarki dimaksud 
dapat bervariasi dengan sub-kriteria ataupun sub-sub kriteria yang lebih kompleks.

2. Langkah 2, masukkan data Matriks Pairwise

Tabel 3.

Contoh Matriks Pairwise Comparison

\begin{tabular}{|l|l|l|l|}
\hline & $\begin{array}{l}\text { Kriteria } \\
\text { A }\end{array}$ & $\begin{array}{l}\text { Kriteria } \\
\text { B }\end{array}$ & $\begin{array}{l}\text { Kriteria } \\
\text { C }\end{array}$ \\
\hline Kriteria A & $\mathbf{1}$ & $\mathrm{X}$ & $\mathrm{y}$ \\
\hline Kriteria B & $\mathbf{1} / \mathrm{X}$ & $\mathbf{1}$ & $\mathrm{Z}$ \\
\hline Kriteria C & $\mathbf{1} / \mathrm{y}$ & $\mathbf{1} / \mathrm{Z}$ & $\mathbf{1}$ \\
\hline
\end{tabular}

3. Langkah 3, Mencari Bobot Prioritas (Vektor Eigen)

Vektor Eigen $=\sum$ Kriteria $/ \mathrm{n}$

4. Langkah 4, Mencari Consistency Ratio Pengukuran ini dimaksudkan untuk mengetahui konsistensi jawaban yang akan berpengaruh pada kesahihan hasil. Rumusnya adalah sebagai berikut:

$$
C I=\frac{\lambda_{\max }-n}{n-1}
$$

Untuk mengetahui apakah CI dengan besaran tertentu cukup baik atau tidak, perlu diketahui rasio yang dianggap baik, yaitu $\mathrm{CR} \leq 0,1$.

Rumus CR (Consistency Ratio) adalah:

$$
C R=\frac{C I}{R I}
$$

Pada dasarnya AHP dapat digunakan untuk mengolah data dari satu responden saja. Untuk responden yang lebih dari satu, maka untuk mendapatkan hasil perhitungannya, harus digabungkan menggunakan rata-rata geometrik dengan rumus sebagai berikut (MARIMIN, 2005):

dimana:

$$
\overline{X_{G}}=\sqrt[n]{\pi^{n}} \cdot X_{i}
$$

$$
\begin{array}{ll}
\overline{X_{G}} & =\text { rata-rata geometrik } \\
\mathrm{n} & =\text { jumlah responden } \\
\mathrm{X}_{\mathrm{i}} & =\text { penilaian oleh responden ke-i }
\end{array}
$$

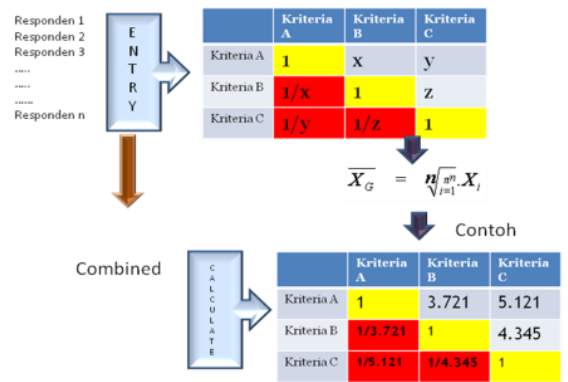

Gambar 5

Responden Penggabungan
Pada tahap kedua adalah pengisian kuesioner pemilihan database software dan proses kuesioner tersebut dengan aplikasi system rekomender untuk mendapatkan kesimpulan tentang strategi pemilihan database software.

\section{PEMBAHASAN}

Dari hasil penelitian ini dapat diungkapkan temuan-temuan teoritis dan faktafakta empiris sehingga diperoleh suatu konstruk teori baru dan atau pengembangan teori yang sudah ada.

\section{Pengujian Kriteria Keputusan}

Pada kriteria Technology memiliki sub kriteria yang menjadi pertimbangan responden berikut hasilnya dengan jumlah responden 6 orang.

Tabel 4

Jawaban Responden Kriteria Technology

\begin{tabular}{lcc}
\hline \multirow{2}{*}{\multicolumn{1}{c}{ Sub Kriteria }} & \multicolumn{2}{c}{ Jawaban } \\
\cline { 2 - 3 } & Ya & Tidak \\
\hline Flexibility & 6 & 0 \\
\hline Implement Ability & 6 & 0 \\
\hline System Requirements & 6 & 0 \\
\hline Real Time Changes & 4 & 2 \\
\hline Back Up System & 6 & 0 \\
\hline Internet Integration & 5 & 1 \\
\hline
\end{tabular}

Pengolahan menggunakan Cochran $Q$ Test didapat hasil :

$$
\begin{aligned}
& \begin{array}{ll}
\mathrm{k}=6 & \mathrm{~dB}=
\end{array}
\end{aligned}
$$

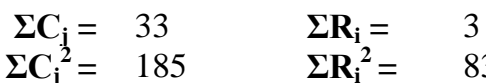

Didapat Qhit = 7 dan Qtab = 9, dengan alpha 5\% didapat Qhit < Qtab maka semua sub kriteria Technlogy dapat di terima (Ho) dan penelitian dapat dilanjutkan.

Pada kriteria Technology memiliki sub kriteria yang menjadi pertimbangan responden berikut hasilnya dengan jumlah responden 6 orang.

Tabel 5

Jawaban Responden Kriteria User

\begin{tabular}{lcc}
\hline \multirow{2}{*}{ Sub Kriteria } & \multicolumn{2}{c}{ Jawaban } \\
\cline { 2 - 3 } & Ya & Tidak \\
\hline Customization & 6 & 0 \\
\hline User Friendliness & 6 & 0 \\
\hline Report \& Analysis Features & 5 & 1 \\
\hline $\begin{array}{l}\text { Integration with Other } \\
\text { Application }\end{array}$ & 6 & 0 \\
\hline
\end{tabular}

Pengolahan menggunakan Cochran $Q$ Test didapat hasil : 


$$
\begin{aligned}
& \mathrm{k}=4 \quad \mathrm{~dB}=3 \\
& \begin{array}{rlrl}
\boldsymbol{\Sigma C}_{\mathbf{j}} & =23 & \boldsymbol{\Sigma R}_{\mathbf{i}}= & 3 \\
\boldsymbol{\Sigma} \mathbf{C}_{\mathbf{i}}^{\mathbf{2}}=133 & \boldsymbol{\Sigma R}_{\mathbf{i}}= & 9
\end{array}
\end{aligned}
$$

Didapat Qhit = 3 dan Qtab = 9, dengan alpha 5\% didapat Qhit < Qtab maka semua sub kriteria Technlogy dapat di terima (Ho) dan penelitian dapat dilanjutkan.

\section{Hasil Pada Kriteria Utama}

Pada pengujian kuesioner yang berjumlah 6 responden didapat hasil untuk Strategi pemilihan Database Software pada Biro TI Bina Sarana Informatika dengan menggunakan Aplikasi Sistem Rekomender Pemilihan Database Software. Berikut hasil pengolahan data pada kriteria utama pada Tabel 6 .

Tabel 6

Prioritas Kriteria Utama

\begin{tabular}{ccl}
\multicolumn{3}{c}{ Prioritas Kriteria Utama } \\
\hline \multirow{2}{*}{ No } & $\begin{array}{c}\text { Bobot } \\
\text { Prioritas }\end{array}$ & Prioritas \\
\hline 1 & $\mathbf{0 . 8 8}$ & Technology \\
\hline 2 & $\mathbf{0 . 5 0}$ & Technology \\
\hline 3 & $\mathbf{0 . 8 8}$ & User \\
\hline 4 & $\mathbf{0 . 8 0}$ & Technology \\
\hline 5 & $\mathbf{0 . 8 8}$ & Technology \\
\hline 6 & $\mathbf{0 . 8 6}$ & User \\
\hline
\end{tabular}

Pada tabel diatas dapat disimpulkan bahwa Technology sebagai prioritas utama dalam pemilihan Database Software dengan bobot nilai tertinggi 0.88 atau $80 \%$. Berikutnya pada pengujian kuesioner sub kriteria level 2 Technology didapat hasil sebagai berikut pada Tabel 7.

Tabel 7

\begin{tabular}{ccl}
\multicolumn{3}{c}{ Prioritas Sub Kriteria Technology } \\
\hline No & $\begin{array}{c}\text { Bobot } \\
\text { Prioritas }\end{array}$ & \multicolumn{1}{c}{ Prioritas } \\
\hline Q1 & 0.24 & Implement Ability \\
\hline Q2 & 0.45 & Implement Ability \\
\hline Q3 & 0.36 & Flexibility \\
\hline Q4 & 0.37 & Back Up System \\
\hline Q5 & 0.28 & Back Up System \\
\hline Q6 & 0.28 & Back Up System \\
\hline
\end{tabular}

Pada Tabel 7 dapat disimpulkan bahwa Back Up System sebagai prioritas utama dalam pemilihan Database Software berdasarkan kriteria Technology dengan bobot nilai tertinggi 0.37 atau $37 \%$. Berikutnya pada pengujian kuesioner sub kriteria level 2 User didapat hasil sebagai berikut pada Tabel 8 .
Tabel 8

Prioritas Sub Kriteria User

\begin{tabular}{ccl}
\hline No & $\begin{array}{c}\text { Nilai } \\
\text { Tertinggi }\end{array}$ & \multicolumn{1}{c}{ Prioritas } \\
\hline Q1 & 0.58 & $\begin{array}{l}\text { Reporting \& Analysis } \\
\text { Features }\end{array}$ \\
\hline Q2 & 0.49 & $\begin{array}{l}\text { Integration with Other } \\
\text { People }\end{array}$ \\
\hline Q3 & 0.48 & User Friendliness \\
\hline Q4 & 0.50 & Customization \\
\hline Q5 & 0.58 & $\begin{array}{l}\text { Reporting \& Analysis } \\
\text { Features }\end{array}$ \\
\hline Q6 & 0.59 & $\begin{array}{l}\text { Integration with Other } \\
\text { People }\end{array}$ \\
\hline
\end{tabular}

Pada tabel diatas dapat disimpulkan bahwa Reporting \& Analysis Features dan Integration with Other People sebagai prioritas utama dalam pemilihan Database Software berdasarkan kriteria Technology dengan bobot nilai tertinggi 0.58 atau $58 \%$ dan 0.59 atau $59 \%$.

\section{Hasil Pada Alternatif Strategi Pemilihan Database Software}

Pengujian kuesioner untuk mencari alternatif strategi permilihan database software, hasil dipresentasikan pada masing-masing sub kreteria utama. Hasil pengolahan data alternatif strategi pada kriteria Technology dengan sub kriteria Flexibility.

Tabel 9

Alternatif Strategi sub kriteria Flexibility

\begin{tabular}{ccc}
\hline No & $\begin{array}{c}\text { Bobot } \\
\text { Eigen } \\
\text { Vektor }\end{array}$ & Prioritas \\
\hline Q1 & 0.58 & MY SQL \\
\hline Q2 & 0.64 & MY SQL \\
\hline Q3 & 0.71 & ORACLE \\
\hline Q4 & 0.66 & ORACLE \\
\hline Q5 & 0.72 & MY SQL \\
\hline Q6 & 0.63 & MY SQL \\
\hline
\end{tabular}

Pada sub kriteria Flexibility didapat prioritas utama sebagai alternatif strategi yaitu MY SQL dengan bobot nilai tertinggi 0.72 atau $72 \%$.

Hasil pengolahan data alternatif strategi pada kriteria Technology dengan sub kriteria Implement Ability.

Tabel 10

Alternatif Strategi sub kriteria Implement

\begin{tabular}{ccc}
\multicolumn{3}{c}{ Ability } \\
\hline No & $\begin{array}{c}\text { Bobot } \\
\text { Eigen } \\
\text { Vektor }\end{array}$ & Prioritas \\
\hline Q1 & 0.53 & MY SQL \\
\hline Q2 & 0.72 & MY SQL \\
\hline Q3 & 0.71 & MY SQL \\
\hline Q4 & 0.62 & ORACLE \\
\hline Q5 & 0.71 & MY SQL \\
\hline Q6 & 0.71 & MY SQL \\
\hline
\end{tabular}


Pada sub kriteria Implement Ability didapat prioritas utama sebagai alternatif strategi yaitu MY SQL dengan bobot nilai tertinggi 0.72 atau $72 \%$. Hasil pengolahan data alternatif strategi pada kriteria Technology dengan sub kriteria System Requirements.

Tabel 11

Alternatif Strategi sub kriteria System Requirements

\begin{tabular}{ccc}
\hline No & $\begin{array}{c}\text { Bobot Eigen } \\
\text { Vektor }\end{array}$ & Prioritas \\
\hline Q1 & $\mathbf{0 . 7 3}$ & ORACLE \\
\hline Q2 & $\mathbf{0 . 7 2}$ & ORACLE \\
\hline Q3 & 0.66 & ORACLE \\
\hline Q4 & 0.73 & ORACLE \\
\hline Q5 & 0.72 & MY SQL \\
\hline Q6 & 0.70 & MY SQL \\
\hline
\end{tabular}

Pada sub kriteria System Requirements didapat prioritas utama sebagai alternatif strategi yaitu ORACLE dengan bobot nilai tertinggi 0.73 atau $73 \%$. Hasil pengolahan data alternatif strategi pada kriteria Technology dengan sub kriteria Real Time Changes.

Tabel 12

Alternatif Strategi sub kriteria Real Time Changes

\begin{tabular}{ccc}
\hline No & $\begin{array}{c}\text { Bobot Eigen } \\
\text { Vektor }\end{array}$ & Prioritas \\
\hline Q1 & 0.69 & ORACLE \\
\hline Q2 & 0.72 & MY SQL \\
\hline Q3 & 0.66 & MY SQL \\
\hline Q4 & 0.66 & ORACLE \\
\hline Q5 & 0.65 & MY SQL \\
\hline Q6 & 0.66 & MY SQL \\
\hline
\end{tabular}

Pada sub kriteria Real Time Changes didapat prioritas utama sebagai alternatif strategi yaitu MY SQL dengan bobot nilai tertinggi 0.72 atau $72 \%$. Hasil pengolahan data alternatif strategi pada kriteria Technology dengan sub kriteria Back Up System.

Tabel 13

Alternatif Strategi sub kriteria Back Up System

\begin{tabular}{ccc}
\hline No & $\begin{array}{c}\text { Bobot Eigen } \\
\text { Vektor }\end{array}$ & Prioritas \\
\hline Q1 & 0.71 & SQL Server \\
\hline Q2 & 0.63 & MY SQL \\
\hline Q3 & 0.72 & MY SQL \\
\hline Q4 & 0.68 & ORACLE \\
\hline Q5 & 0.68 & ORACLE \\
\hline Q6 & 0.73 & ORACLE \\
\hline
\end{tabular}

Pada sub kriteria Back Up System didapat prioritas utama sebagai alternatif strategi yaitu ORACLE dengan bobot nilai tertinggi 0.73 atau $73 \%$. Hasil pengolahan data alternatif strategi pada kriteria Technology dengan sub kriteria Internet Integration.
Tabel 14

Alternatif Strategi sub kriteria Internet Integration

\begin{tabular}{ccc}
\hline No & $\begin{array}{c}\text { Bobot } \\
\text { Eigen } \\
\text { Vektor }\end{array}$ & Prioritas \\
\hline Q1 & 0.63 & MY SQL \\
\hline Q2 & 0.63 & ORACLE \\
\hline Q3 & 0.66 & MY SQL \\
\hline Q4 & 0.33 & MY SQL \\
\hline Q5 & 0.63 & ORACLE \\
\hline Q6 & 0.57 & MY SQL \\
\hline
\end{tabular}

Pada sub kriteria Internet Integration didapat prioritas utama sebagai alternatif strategi yaitu MY SQL dengan bobot nilai tertinggi 0.66 atau $66 \%$. Hasil pengolahan data alternatif strategi pada kriteria User dengan sub kriteria Customization.

Tabel 15

Alternatif Strategi sub kriteria Customization

\begin{tabular}{ccc}
\hline No & $\begin{array}{c}\text { Bobot } \\
\text { Eigen } \\
\text { Vektor }\end{array}$ & Prioritas \\
\hline Q1 & 0.68 & SQL Server \\
\hline Q2 & 0.57 & MY SQL \\
\hline Q3 & 0.72 & MY SQL \\
\hline Q4 & 0.62 & MY SQL \\
\hline Q5 & 0.67 & ORACLE \\
\hline Q6 & 0.68 & MY SQL \\
\hline
\end{tabular}

Pada sub kriteria Customization didapat prioritas utama sebagai alternatif strategi yaitu MY SQL dengan bobot nilai tertinggi 0.72 atau $72 \%$. Hasil pengolahan data alternatif strategi pada kriteria User dengan sub kriteria User Friendliness.

Tabel 16

Alternatif Strategi sub kriteria User Friendliness

\begin{tabular}{ccc}
\hline & $\begin{array}{c}\text { Bobot } \\
\text { Eigen } \\
\text { Vektor }\end{array}$ & Prioritas \\
\hline Q1 & $\mathbf{0 . 7 0}$ & MY SQL \\
\hline Q2 & $\mathbf{0 . 4 5}$ & ORACLE \\
\hline Q3 & 0.72 & MY SQL \\
\hline Q4 & 0.72 & MY SQL \\
\hline Q5 & 0.59 & MY SQL \\
\hline Q6 & 0.54 & MY SQL \\
\hline
\end{tabular}

Pada sub kriteria User Friendliness didapat prioritas utama sebagai alternatif strategi yaitu MY SQL dengan bobot nilai tertinggi 0.72 atau $72 \%$. Hasil pengolahan data alternatif strategi pada kriteria User dengan sub kriteria Reporting \& Analysis Features. 
Tabel 17

Alternatif Strategi sub kriteria Reporting \& Analysis Features

\begin{tabular}{ccc}
\hline No & $\begin{array}{c}\text { Bobot } \\
\text { Eigen } \\
\text { Vektor }\end{array}$ & Prioritas \\
\hline Q1 & 0.37 & SQL Server \\
\hline Q2 & 0.59 & MY SQL \\
\hline Q3 & 0.72 & MY SQL \\
\hline Q4 & 0.71 & ORACLE \\
\hline Q5 & 0.62 & ORACLE \\
\hline Q6 & 0.68 & ORACLE \\
\hline
\end{tabular}

Pada sub kriteria Reporting \& Analysis Features didapat prioritas utama sebagai alternatif strategi yaitu ORACLE dengan bobot nilai tertinggi 0.71 atau $71 \%$. Hasil pengolahan data alternatif strategi pada kriteria User dengan sub kriteria Integration with Other Application.

Tabel 18

Alternatif Strategi sub kriteria Integration with Other Application

\begin{tabular}{ccc}
\hline No & $\begin{array}{c}\text { Bobot } \\
\text { Eigen } \\
\text { Vektor }\end{array}$ & Prioritas \\
\hline Q1 & 0.67 & MY SQL \\
\hline Q2 & 0.66 & ORACLE \\
\hline Q3 & 0.67 & MY SQL \\
\hline Q4 & 0.72 & MY SQL \\
\hline Q5 & 0.70 & ORACLE \\
\hline Q6 & 0.64 & ORACLE \\
\hline
\end{tabular}

Pada sub kriteria Integration with Other Application didapat prioritas utama sebagai alternatif strategi yaitu MY SQL dan ORACLE dengan bobot nilai tertinggi 0.72 atau $72 \%$ dan 0.70 atau $70 \%$.

\section{Intepretasi global Alternatif Strategi} Pemilihan Database Software

Tabel 19

Nilai Eigen Vektor Global dengan Kriteria Technology

\begin{tabular}{lccccccc}
\hline Goal & Q1 & Q2 & Q3 & Q4 & Q5 & Q6 & $\begin{array}{c}\text { Eigen } \\
\text { Vektor }\end{array}$ \\
\hline MY SQL & 0.72 & 0.72 & 0.72 & 0.72 & 0.72 & 0.66 & 0.41 \\
\hline $\begin{array}{c}\text { SQL } \\
\text { Server }\end{array}$ & 0.71 & 0.62 & 0.73 & 0.69 & 0.73 & 0.63 & 0.39 \\
\hline ORACLE & 0.22 & 0.22 & 0.23 & 0.27 & 0.71 & 0.33 & 0.20 \\
\hline
\end{tabular}

Hasil pada Tabel 19 diatas dapat disimpulkan bahwa dengan pendekatan kriteria technology didapat MY SQL menjadi prioritas utama

Tabel 20

dalam pemilihan database software dengan bobot nilai 0.41 atau $41 \%$. Software menggunakan Rekomender Pemilihan Database Software secara menyeluruh atau global. Pada kriteria utama Technology didapat alternatif strategi sebagai berikut :

Pada tahap ini dijelaskan hasil dari

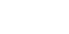

Nilai Eigen Vektor Global dengan Kriteria User

\begin{tabular}{lccccccc}
\hline \multicolumn{1}{c}{ Goal } & Q1 & Q2 & Q3 & Q4 & Q5 & Q6 & $\begin{array}{c}\text { Eigen } \\
\text { Vektor }\end{array}$ \\
\hline MY SQL & 0.72 & 0.72 & 0.72 & 0.72 & 0.72 & 0.72 & 0.40 \\
\hline SQL & & & & & & & \\
Server & 0.67 & 0.45 & 0.71 & 0.70 & 0.67 & 0.45 & 0.39 \\
\hline ORACLE & 0.68 & 0.35 & 0.37 & 0.24 & 0.68 & 0.35 & 0.21 \\
\hline
\end{tabular}


Hasil pada Tabel 20 diatas dapat disimpulkan bahwa dengan pendekatan kriteria User didapat MY SQL menjadi prioritas utama dalam pemilihan database software dengan bobot nilai 0.40 atau $40 \%$. Dengan menggabungkan bobot nilai kriteria utama yaitu Technology dan User didapat hasil sebagai berikut :

Tabel 21

Nilai Eigen Vektor Global

\begin{tabular}{lccl}
\hline \multicolumn{1}{c}{ Goal } & Technology & User & $\begin{array}{l}\text { Eigen } \\
\text { Vektor }\end{array}$ \\
\hline$M Y S Q L$ & 0.41 & 0.40 & 0.41 \\
\hline SQL & & & \\
Server & 0.39 & 0.39 & 0.39 \\
\hline ORACLE & 0.20 & 0.21 & 0.21 \\
\hline
\end{tabular}

Hasil pada Tabel 21 diatas dapat disimpulkan bahwa dengan pendekatan dua kriteria utama yaitu Technology dan User didapat bahwa MY SQL menjadi prioritas utama dalam pemilihan database software dengan bobot nilai 0.41 atau $41 \%$ berikutnya SQL Server manjadi prioritas kedua dengan nilai 0.39 atau $39 \%$ dan ORACLE menjadi prioritas terakhir dengan nilai 0.21 atau $21 \%$.

Dari Eigen Vektor diatas didapat Rasio Kosistensi Hirarki sebesar 1.84 atau lebih besar dari 0.1 sehingga tingkat kosistensi responden tidak sempurna atau tidak konsisten.

Dengan menggunakan Sistem Rekomender Pemilihan Database Software pemilihan alternatif Database Software dapat diketahui yaitu dari 6 responden didapat bahwa Aplikasi Database MY SQL menjadi prioritas utama dengan tingkat tidak konsisten $18.4 \%$.

\section{PENUTUP}

Database Software merupakan Aplikasi Database yang digunakan yang mengolah Data kecil ataupun besar, dengan pemilihan Database Software yang tepat dapat menunjangn visi dan misi organisasi khususnya Departemen.

Pada pengolahan pemilihan Database Software ini menggunakan Aplikasi Sistem Rekomender Pemilihan Database Software yang dibuat dengan metode Analytical Hierarcy Process (AHP) untuk mempermudah dalam pengolahan data dan intrepretasi.

Semua sub kriteria yang ada pada priteria utama yaitu Technology dan User dapat digunakan untuk mengukur pemilihan Database Software. Pengolahan data hasil 6 (enam) responden dengan menggunakan Sistem Rekomender Pemilihan Database Software didapat hasil bahwa MY SQL adalah aplikasi database yang sesuai dengan keinginan Responden dan sesuai dengan kebutuhan organisasi yaitu Bina Sarana Informatika khususnya Biro TI BSI dengan bobot nilai 0.41 atau $41 \%$, berikutnya SQL Server manjadi prioritas kedua dengan nilai 0.39 atau $39 \%$ dan ORACLE menjadi prioritas terakhir dengan nilai 0.21 atau $21 \%$

Dengan dilakukannya penelitian ini maka penerapan database software yang sesuai dengan visi misi perusahaan dapat dilaksanakan dengan dan dapat meminimalisasi resiko yang ditimbulkan karena kegagalan sistem serta strategi IT yang sejalan dengan strategi bisnis di perusahaan akan tercapai.

Penelitian yang dilakukan ini berhubungan dengan kondisi organisasi dimana membantu mengambil keputusan dalam memilih database software dan perlu pengembangan sistem jika kriteria pemilihan mengalami perubahan. Konsistensi perlu diperhatikan pada pairwise comparisons (perbandingan berpasangan) agar tidak terjadi inkonsistensi dengan cara mengukur instrumen pertanyaan yang akan diajukan dalam kuesioner. Perlu dibuatkan prosedur yang baku mengenai Standar Operasional Sistem Rekomender Pemilihan Database Software

\section{REFERENSI}

Alanbay, Oyku. (2005). Selection of Enterprise Resource Planning (ERP) Systems. Istanbul Bilqi University. Turkey.

Amborowati, Aradyah. (2007). Sistem Pendukung Keputusan Pemilihan Karyawan Berprestasi Berdasarkan Kinerja. STMIK AMIKOM. Jogyakarta.

Carpenter, Stanley D. M. (2005). Military Leadership in The british Civil Wars. The Genius of This ages. Routledge. 
Cheng, Eddie W L; Li, Heng. (2001). Information priority-setting for better resource allocation using analytic hierarchy process $(A H P)$. Information Management \& Computer Security. $9.2 / 3: 61-70$.

Danner, Marion; Hummel, J Marjan; Volz, Fabian; van Manen, Jeannette G; Wiegard, Beate. (2011). Integrating patients' views into health technology assessment: Analytic hierarchy process (AHP) as a method to elicit patient preferences. International Journal of Technology Assessment in Health Care. 27.4 : 369-75.

Davies, Mark. (2001). Adaptive AHP: A review of marketing applications with extensions. European Journal of Marketing. 35.7/8 872-893.

Dzacko, Haidar. (2007). Basis Data (Database). Mangosoft. Rusia

Earl. (2000). The Practice of Social Research. Belmont CA. Wadsworth.

Fard, Mohammad Taghi Taghavi; Jafari, Hamid Reza; Shojaie, Seyed Ehsan. (2012). Analysis Expert System Factors in IT Project Selection using Fuzzy AHP. Interdisciplinary Journal of Contemporary Research In Business. $4.8: 512-523$

Kadir, Abdul. (2005). Konsep \& Tuntunan Praktis Basis Data. Andi Offset. Yogyakarta.

Kord, Baqer; Eslamkhah, Mahdi. (2011). Ranking Effectiveness of Industrial Companies Based On Information Technology Index By AHP/DEA. Interdisciplinary Journal of Contemporary Research In Business. $2.12: 66-80$.

Parthasarathy, S; Anbazhagan, N. (2007). Evaluating ERP Implementation Choices Using AHP. International Journal of Enterprise Information Systems 3.3 : 52-65.

Purwanto, Ari. (2009). Metode Analisis Rekomendasi pada Sistem Rekomendasi. UPI. Jakarta.
Saaty, Thomas L. (2008). Decision making With The Analytic Hierarchy Process. University of Pittsburgh. USA

Sinaga, Johanes. (2008). Strategi Proses Migrasi Proprietary Software ke Open Source Software di Perusahaan dengan pendekatan Analytical Hierarchy Process (AHP). Indonesia

Supratikto. (2009). Memproteksi Pasar dalam Negri.

Waliyanto. (2000). Sistem Basis Data Analisis dan Pemodelan data. J\&J Learning. Yogyakarta.

Wan, Jiangping; Zhang, Hui; Wan, Dan. (2011). Evaluation on Information Technology Service Management Process with AHP. Technology and Investment. $2.1: 38-46$ 
Jurnal Informatika. Vol. I No. 2 September 2014 